\title{
Factors of Dividend Payout Ratio and Influence on Company Value (Case Study on LQ 45 Companies in Indonesia Stock Exchange on the 2011-2015)
}

\author{
Erni Alfisah, and Kurniaty* \\ ${ }^{1}$ Department of Management, Faculty of Economy, Islamic University of Kalimantan Muhammad Arsyad Albanjari Banjarmasin- \\ South Kalimantan, Indonesia \\ ${ }^{a}$ Correspondent author's email: sidol_99 [AT] yahoo.com
}

\begin{abstract}
The purpose of this study was to examine the effect of return on equity on the dividend payout ratio, the effect of the company's growth on the dividend payout ratio, the effect of free cash flow on the dividend payout ratio, the effect of leverage on the dividend payout ratio, and the effect of the dividend payout ratio on firm value. The model used in data analysis is a simple multiple regression model because the measurement of the dependent and independent variables in this study is in the form of numbers with a ratio scale measurement instrument and independent variables used by more than one. The results of this study indicate that the return on equity has a significant effect on the dividend payout ratio, growth has no significant effect on the dividend payout ratio, free cash flow has a significant effect on dividend payout ratio, leverage has no significant effect on the dividend payout ratio, and dividend payout ratio has a significant effect on the value of the company.
\end{abstract}

Keywords--- Return on Equity, Free Cash Flow, Leverage, Dividend Payout, and Value

\section{INTRODUCTION}

The dividend policy is a decision taken by the company, for the sharing of net profits to shareholders in the form of dividends (holding profit for investment). If the company was choose to division profit as dividend, it will reduce the retained earnings and subsequently reduce the total source of internal funds or internal financing. If internal funds are insufficient, companies will be forced to seek external funds, and issue shares or bonds.

Conversely, if the company chooses to hold the profits earned to be reinvested to the projects. Which is profitable in order to increase the company's growth, the profits to be shared with shareholders will be reduced. Thus it should be when the profit will be distributed and when it will be withheld while maintaining the company's goal of increasing the value of the company (1). The dividend policy is still a debate. Dividend were found three main dividend issues: First, the dividend policy is irrelevant, or something that does not need to be taken into account specifically. Second, the size of the dividend has a linear relationship with the high low stock prices. For companies that go public, the value of the company is reflected in its share price. The higher of stock price, the higher of value of the company. Third, dividend policy has a negative relationship to stock price. That is, the lower the dividend, the higher the company's stock price.

To maximize the companies are generate and increase the value of the company. The company is faced with a decision on dividend policy to be given to shareholders. The higher company value, the greater the prosperity that will be received by the owner of the company or investor (1). The size of the dividend depends on the dividend policy of each company, so management considerations are necessary. The dividend policy is basically to determine how many portions of profit to be given to its shareholders, called dividend payout ratio (DPR). Therefore, companies in determining the amount of dividend payout ratio are always different.

Many factors influence the policy of the Dividend Payout Ratio. Among other things, the rent ability own capital, cash position, debt to equity ratio, the degree of operating leverage (Dol) and tax rate. The size of the company, agency cost, leadership concentration, Free Cash Flow, and transaction costs (2).

This study uses return on equity (ROE), free cash flow (FCF), and leverage (DER) as the forming of dividend payout ratio (DPR), while closing price (CP) and price earning ratio (PER) as forming company value. ROE is the ability of the capital itself to generate profits for shareholders. Whereas, DPR is a percentage from profits will be paid to the shareholders as dividends. ROE is one of the factors affecting the DPR's policy. The greater the profit generated, the greater the percentage of profits that will be distributed to shareholders as dividends. The results of the research that yielded the profits had a significant positive influence on the dividend performed by Abdelsalam et al. (30), Chen et al. (4). However, studies 
conducted by Grullon et al. (5) produced different results, where the increase in profits was not followed by an increase in dividend payouts.

The faster growing of a company, the greater needed for funds to finance that growth. Companies usually prefer to hold profits to finance corporate growth rather than pay dividends. Thus, it can be said that the higher the growth rate, the lower the House. The results of the study that produced significant negative growing on dividend were performed by DeAngelo et al. (6) and Truong and Heaney (7).

FCF is the excess cash flow required to fund an investment project that has a positive NPV. The higher the FCF is owned by the company, the higher the cash available in the company. Conflict occurs when determining the proportion of FCFs distributed as dividends and as retained earnings for reinvestment, on projects expected to generate future profits. Shareholders prefer FCF to be used to pay dividends, and management instead wants FCF to be used to finance profitable investment projects. So, get increase the company's growth. Fenn and Liang (8) and Manos (9) found evidence of FCF having a significant positive effect on dividends. However, research conducted by Gong (10) shows that FCF has a significant negative effect on DPR.

The effect of leverage on dividends can be explained using the thought of 'Debt covenant hypothesis' Gong (10) states firms using high leverage will cause the company to reduce dividend payouts. The basis of Kalay's thought is to avoid welfare transfer from the creditors to the shareholders. The research that reinforces Kalay's thinking is a study conducted by Holmen et al. $(11,4)$. However, research conducted by Renneboog and Trojanonowski (12) yielded different results, where leverage had a significant positive effect on dividends, while research conducted by Houston (13), and Kouki (14) produced results indicating that leverage had no significant effect on dividends.

According to 'Dividend signaling theory', dividend change is a signal about the future prospects of the firm. The decline in dividends is considered by investors as bad news, because it indicates the condition and prospects of the company is not good, resulting in negative reaction investors. On the contrary, rising dividend payout is considered good news, as it indicates the condition and prospects of the firm in good condition. Research shows that dividends have a significant positive effect on firm value.

Based on the results of previous research, it can be concluded there has been a significant difference (gap) about the influence of ROE on DPR, Growth influence on DPR, FCF influence on DPR, Leverage influence on DPR, and House influence on firm value. This provides an opportunity for a more in-depth study of these variables. Thus, the objective of this study was evaluate of Testing and explain the effect of Return on Equity (ROE) on the DPR, influence of growth on the DPR, Free Cash Flow (FCF) on the DPR, leverage (DER) on the DPR, and DPR on the value of the Company.

\section{THEORETICAL STUDIES AND CONCEPTUAL MODELS}

The dividend policy concerns the issue of use which is the right of shareholders. Basically, such profits may be distributed as dividends or retained for reinvestment. The larger of dividend, will the limited internal funds available to finance various investment projects. If not enough, the company will be forced to seek external funds, issue shares or bonds. Thus, it should be when the profit will be distributed, and when it will be withheld while keeping in mind the company's goal of increasing the value of the company (1).

\section{Dividend Policy Theory}

There are several opinions or theories about dividend policy:

First: Dividend irrelevance theory, this opinion put forward by Modigliani and Miller (MM), the value of a company is not determined by the big and small of the DPR. But, it is determined by the net profit before tax (EBIT) and the risk class of the company. Second: The Bird in the Hand Theory Most shareholders prefer current dividend payments rather than delaying them to be realized in the form of capital gains. The tax tariff for capital gains is often lower than for dividends. However, many shareholders are often of current dividends. Because with the current dividend payment then the receipt of money is certain, whereas if postponed there is a possibility that what is expected to miss (1). Three;Tax differences theory This theory was proposed by Litzenberger and Ramaswamy. They claim that because of the tax on dividends and capital gains, investors prefer capital gains because they can delay paying taxes. Therefore, investors require a higher rate of return on stocks that provide high dividend yields, low capital gains rather than low dividend yields, high capital gains. If the tax on dividends is greater than the tax on capital gains, this difference will be felt if management believes that the irrelevant dividend theory of MM is true, then the company does not need to pay attention to how much dividend to divide. If they embrace the theory of the bird in the hand, they must divide the entire EAT in dividends. And if management tends to trust Tax Differential Theory, they should hold all EAT or DPR $=0 \%$. Four: Signaling Theory There is empirical evidence if dividend increases, often followed by stock price increases. On the other hand, the decrease in dividend generally causes the stock price to fall. This phenomenon can be considered as evidence that investors prefer dividends rather than capital gains, but MM argues that an increase in dividends above is usually a "signal" to investors. That company management foresees a good income in the future, conversely, a decrease in dividend or an increase in dividends below the normal (usually) increase is believed to be a signal that the company faces a difficult period in the future. Like other dividend theories, the theory of "Signaling Hypothesis" is also difficult to prove empirically. It is evident that the dividend 
changes contain some information, but it is difficult to say whether the increase and decrease in prices. After the increase and decrease in dividends is solely due to the "signal" effect and the preference for dividends.

\section{Factors Affecting Dividend Policy}

In practice, there are several factors that influence management in determining dividend policy: First; Debt Agreement.In general, inter-company debt agreements with creditors limit dividend payouts. For example, dividends can only be granted. If the debt obligations can be met by the company and the financial ratios show the bank in good condition. Second; Restrictions from preferred stock There is no dividend payment for a common stock if the preferred stock dividend has not been paid. Three; Availability of cash Dividends in the form of cash (cash dividend) can only be paid if enough cash is available. If liquidity is good, the company can pay dividends. Four; Control If management wants to retain control of the company, it tends to hesitate to sell new shares. So that it prefers to hold earnings to meet the needs of the fund, resulting in paid dividends being small. This factor becomes important in relatively small companies. Five; The need funds for investment A growing company always needs new funds to invest in profitable projects. The new funding source which is its own capital (equity) can be the sale of new shares and retained earnings. Management tends to take advantage of retained earnings because the sale of new shares raises the cost of the flotation cost. Therefore, the greater is funding requirement the smaller the dividend payout ratio. Six; Profit fluctuations If the firm's earnings tend to be stable, the firm can distribute relatively large dividends without fear of lowering dividends. If, the profit suddenly declined then vice versa. And if the firm's earnings fluctuate, the dividend is otherwise small in order to maintain its stability.

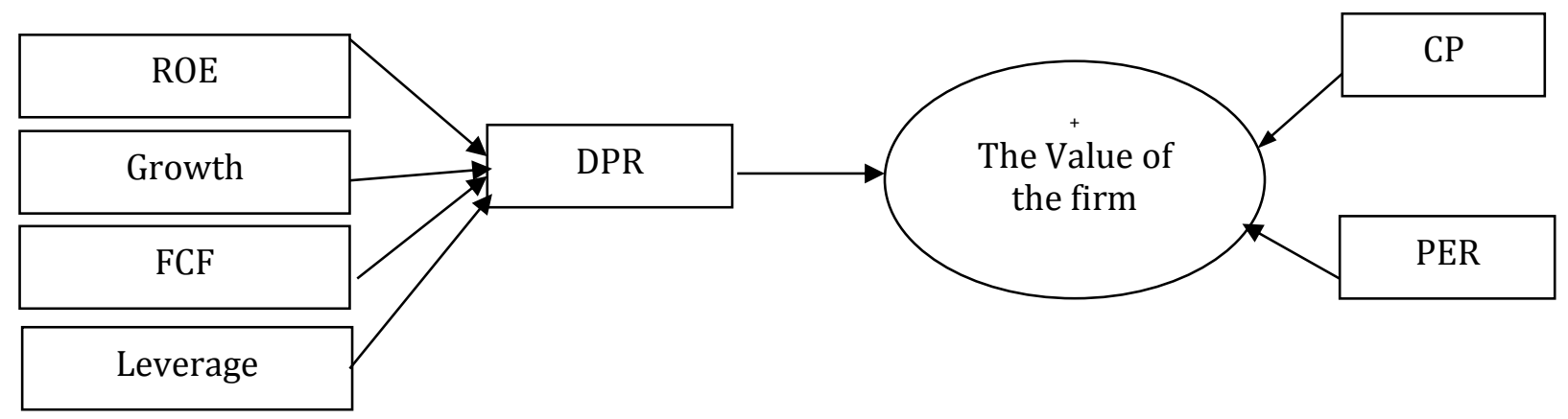

Figure Model of research

\section{RESEARCH METHODS}

\section{Population and Sample}

In this study the population was companies that have been listed in the index of LQ45 in Indonesia Stock Exchange, during the period 2011-2015 with a population of 85 companies. Samples were taken in this research were companies that have been included in the list of LQ 45 indexes in Indonesia Stock Exchange during the period 2011-2015. Sample determination was done by approaching "Non-probability random sampling" with "purposive sampling" method, where the sample selection was based on certain criteria according to the required information. The sample criteria are:

1. Companies listed in the LQ45 Index within the period 2011-2015 (5 years).

2. Publish financial statements during the period 2011-2015.

3. Ever distributed dividends during the period 2011-2015.

Based on the criteria mentioned above, the company that be the sample in this research can be seen in table $\mathbf{1}$. 
Table 1. Sample of the research

\begin{tabular}{|l|l|l|}
\hline NO & CODE OF COMPANY & NAME OF COMPANY \\
\hline 1 & AALI & Astra Agro Lestari Tbk \\
\hline 2 & ADRO & Adaro Energy Tbk \\
\hline 3 & ASII & Astra Internasional Tbk \\
\hline 4 & BBCA & Bank Central Asia Tbk \\
\hline 5 & BBNI & Bank Negara Indonesia Tbk \\
\hline 6 & BBRI & Bank Rakyat Indonesia(Pesero) Tbk \\
\hline 7 & BMRI & Bank Mandiri (Pesero) Tbk \\
\hline 8 & CPIN & Charoen Pokphand Indonesia Tbk \\
\hline 9 & INDF & Indofood sukses Makmur \\
\hline 10 & INTP & Indicement Tunggal prakasa Tbk \\
\hline 11 & JSMR & Jasa Marga Tbk \\
\hline 12 & KLBF & Kalbe Farma Tbk \\
\hline 13 & LPKR & Lippo Karawaci Tbk \\
\hline 14 & LSIPPP & London Sumatra Indonesia Tbk \\
\hline 15 & PGAS & Perusahaan Gas Negara (Pesero) Tbk \\
\hline 16 & PTBA & Tambang Batu Bara bukit Asam Tbk \\
\hline 17 & SMGR & Semen Gresik (Pesesro) Tbk \\
\hline 18 & TLKM & Telekomunikasi Indonesia Tbk \\
\hline 19 & UNTR & United tractor Tbk \\
\hline 20 & UNVR & Unilever Indonesia Tbk \\
\hline 21 & GGRM & Gudang garam Tbk \\
\hline
\end{tabular}

Source: data processed

The sample of this research was an LQ45 company that listed in Indonesia Stock Exchange 2011 until 2015with annual report, annual financial report and ICMD continuously. The number of samples was 21 companies x 5 years $=105$ samples.

\section{Independent Variables}

The independent variables used in this study are as follows: Return on equity ratio (ROE), Growth (Growth), Free Cash Flow (FCF), Leverage (DER) as follows:

1). (X1) Return on equity (ROE)

2). (X2) Growth

3). (X3) Free Cash Flow (FCF)

4). (X4) Leverage (DER)

\section{Dependent Variables}

The dependent variable used in this study was Dividend payout ratio and Company Value as follows:

1. (Y1) Dividend Payout Ratio (DPR)

2. (Y2) Value of the Company, using 2 indicators, namely closing Price (Y2.1) and Price earnings ratio (PER) (Y2.2)

DPR = Dividend Payout Ratio

\section{Data Analysis Technique}

The model used in data analysis in this study was a simple multiple regression model. because the measurement of the dependent and independent variables in this study was a number, with the measuring scale and independent variables used more than one so, the empirical model used was as follows:

First equation:

$\mathrm{DPR}=\beta 0+\beta 1 \mathrm{ROE}+\beta 2 \mathrm{FCF}+\beta 3$ GROWTH $+\beta 4$ DER

Information:

$\begin{array}{ll}\mathrm{DPR} & =\text { Dividend Payout Ratio } \\ \beta 0 & =\text { Constanta } \\ \text { ROE } & =\text { Return on Equity }\end{array}$




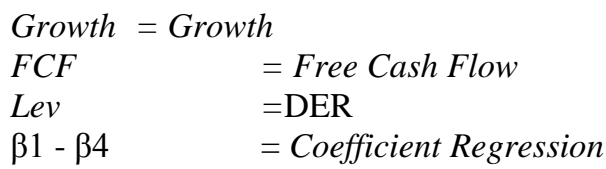

Second Equation:

$\mathrm{DPR}=\beta 0+\beta 1 \mathrm{ROE}+\beta 2 \mathrm{FCF}$

Information:

DPR = Dividend Payout Ratio/ Corporate Value

B0 $\quad=$ Constants

ROE $\quad=$ Return on Equity

$\mathrm{FCF} \quad=$ Free Cash Flo

\section{RESULTS AND DISCUSSIONS}

Based on the results of SPSS data processing, then the relationship between variables with multiple linear regression analysis can be seen as follows:

Table 2. Multiple Linear Regression Analysis

\begin{tabular}{lclll}
\hline Variable & Unstandardized & Standardized & significant & Remark \\
\hline Coefficient (B) & & & & \\
\hline Constant & 13.498 &, 002 & & \\
ROE &, 260 &, 281 & 0.007 & Significant \\
Growth &,- 002 &,- 039 & 0.698 & no significant \\
FCF & 132,010 &, 351 & 0.001 & Significant \\
Leverage &, 155 &, 109 & 0.296 & no significant \\
\hline
\end{tabular}

Based on the above table, the multiple linear regression equation systematically as follows:

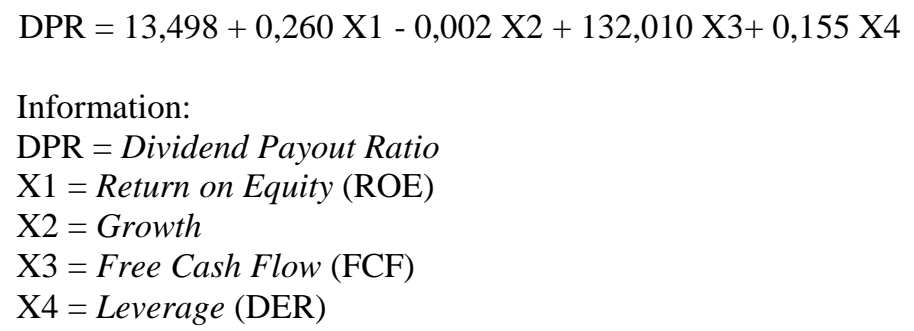

\section{Test T (Partial test)}

The $\mathrm{T}$ test hypothesis is:

$\mathrm{H} 0: \mathrm{Bi} \quad=0=1,2,3,4$

$\mathrm{H} 1: \mathrm{Bi}, \quad /=0=1,2,3,4$

1. H1 Testing

H1: Return On Equity has a significant influence on Dividend Payout Ratio.From the result of multiple linear regression at the level of significance 0,05 indicate that ROE variable has a value of 0,007 less than 0,05 or in other words alternative hypothesis one (H1). Thus it can be concluded that ROE has a significant influence on the DPR.

2. H2 Testing

H2: Growth was no significant effect on DPR.

From the test results seen that Growth variable has a value of siq 0.698 greater than 0.005 , based on the test criteria, then $\mathrm{H} 0$ accepted or $\mathrm{H} 1$ rejected, it means Growth no significant effect on the DPR.

3. H3 Testing

H3: Free Cash Flow influential significant to Dividend Payout Ratio.

From the test results showed that the FCF variable has a value of $0.001 \mathrm{siq}$ less than 0.05 . Based on the test criteria, H1 accepted means that the FCF has a significant influence on the DPR. 
4. H4 Testing

H4: Leverage was no significant effect on DPR.

From the test results seen that leverage variables have a value of 0.296 greater than 0.05 . Based on the test criteria, then $\mathrm{H} 0$ received or $\mathrm{H} 4$ was rejected. The Meaning of leverage does not affect the DPR.

\section{Test F (Testing simultaneously) \\ Hypothesis in Test $\mathrm{F}$ was: \\ $\mathrm{H} 0: \mathrm{B} 1=\mathrm{B} 2=\mathrm{B} 3=\mathrm{B} 4=0$}

$\mathrm{H} 1$ : there is at least one $\mathrm{B} 1=0, \mathrm{i}=1,2,3,4$

From the analysis of the attachment, obtained the value of $\mathrm{F}=4.925$ with the value of $\mathrm{p}(\mathrm{siq})=0.001$ was smaller than 0.05 . Thus it was decided to reject $\mathrm{H} 0$ or at least there were two variables that have a significant effect on the DPR.

\section{Partial Least Squares Analysis (PLS)}

Variable 'DPR' was manifest variables (not latent) in which the value of observations obtained from the regression equation in the previous section by using a significant coefficient (different from 0 ), ie: $\mathrm{DPR}=13,498+0,260 \mathrm{ROE}+132,010 \mathrm{FCF}$

And Company Value was a latent variable with CP and PER indicator that has a formative measurement model. To find out whether there was influence from the DPR of Representatives on Corporate Value. Partial Least Squares (PLS) can be used since there are latent variables and relatively small sample sizes $(n=84)$ which the full analysis can be seen in the appendix with the help of Smart PLS Program. H5 Testing: The dividend payout ratio has a significant effect on firm value

\section{Hypothesis Testing 5}

H5: Dividend Payout Ratio has a significant effect on Company Value.

From the result of analysis using PLS was got big influence 0,341 with P value equal to 0,031 . And on the result, it is also seen that Closing Price was a significant indicator to form Company Value, while PER was not significant. Thus there was a positive and significant influence of the House on the value of the Company with $\mathrm{CP}$ indicators.

\section{DISCUSSION}

\section{Effect of Return on Equity (ROE) on Dividend Payout Ratio (DPR)}

Hypothesis 1 states that ROE has a significant effect on DPR accepted with a coefficient ( $\beta$ ) 0,260 and p-value (Sig) 0,007. The direction of ROE's influence on DPR was positive, which means the greater the ROE, the greater the DPR. The determination of percentage paid as the dividend was determined by the ability of the capital itself to generate profit. The greater the profit generated from the capital itself, the greater the percentage to be paid as dividends. This is in accordance with the research conducted by AbdelSalam et al. (3), Chen et al. (4).

\section{Growth Influence of Dividend Payout Ratio (DPR)}

The Hypothesis of 2 states that Growth has a significant effect on DPR was rejected by a coefficient $(\beta)-0.002$ and pvalue (Sig) 0.698. The direction of growing influence against the DPR was negative which means the greater of growth, the smaller of DPR. Determination of the percentage paid as the dividend was not significantly influenced by the growth rate of the company. Because in financing growth, companies can use other sources such as loans (debt). Fenn et al. (8) explains that debt can act as a substitute for dividends to reduce agency issues. Debt has good benefits for the company because debt can motivate managers and organizations to make efficiency. The results of this study were not in accordance with research conducted by DeAngelo et al. (6), Truong and Heaney (7) stating that the company's growth has a significant negative impact on the DPR.

\section{Effect of Free Cash Flow (FCF) to Dividend Payout Ratio (DPR)}

Hypothesis 3 states that FCF has a significant effect on DPR accepted with a coefficient ( $\beta$ ) 132,01 and p-value (Sig) 0,001. A direction of the FCF's influence on the DPR was positive which means the bigger the FCF, the greater the DPR. Determination of the percentage paid as the dividend was determined by the amount of FCF owned. According to DeAngelo et al.(6), the existence of FCF within the company can lead to a conflict of interest between management and company shareholders (agency problem), and to reduce the problem was required agency cost. Jensen offers another explanation of the role of dividends to reduce agency issues (in this case the FCF). Associated with FCF, the problem arises was how to motivate managers to pour the existing cash, so as not to be used to investment that was not profitable in the future. The results of this study were in accordance with research conducted by Fenn et al. (8) found evidence of FCF having a significant positive effect on dividends. 


\section{Effect of leverage (DER) on Dividend Payout Ratio (DPR)}

The Hypothesis of 4 states that the DER has a significant effect on DPR was rejected with a coefficient ( $\beta$ ) 0,155 and $p$ (Sig) 0,296. The direction of DER's influence on DPR was positive which means the bigger the DER, the bigger the DPR. The results of this study contradict the thinking of the debt covenant hypothesis (14) states companies using high leverage. May cause the company to reduce or will not increase its dividend payout. The results of this study confirm the research conducted by Huston (13) where leverage has no significant positive effect on the DPR

\section{Effect of Dividend Payout Ratio (DPR) on Corporate Value.}

Hypothesis 5 states that the House of Representatives has a significant effect on the value of the company accepted with the coefficient ( $\beta$ ) 0.341 with a p-value (Sig) 0.031 . The direction of the DPR influence on corporate value was positive which means large DER, the greater the value of the firm. The company paying the dividend will indicate, the company has a low agency problem, so it will be able to increase the value of the company. From the view of investors who want dividends, dividends can be used as a mechanism to increase company value. There is three thoughts based on investor preferences that tend to favor dividends: (1) The bird in the hand theory, (2) clientele effect, (3) catering theory. The consequence of these three thoughts was that companies will tend to attract "clientele" who want a dividend payment. The view of dividend signaling theory discloses that dividend change was a clue about the prospect of the company in the future. Increased dividend payout by the company to shareholders was considered by investors as good news, as it indicates the condition and prospects of the company in good condition. There by generating a positive reaction by investors.

\section{CONCLUSIONS}

Based on the above description and discussion are taken some conclusions:

Return on equity (ROE) was a significant effect on the dividend payout ratio (DPR) with positive direction, where coefficient ( $\beta$ ) 0,260 and p-value (Sig) 0,007. This result was in accordance with research conducted by $(3,4)$

Growth was no significant effect on the dividend payout ratio (DPR) with negative direction, where coefficient $(\beta)-0,002$ and p-value (Sig) 0,698. The results of this study were not in accordance with research conducted by DeAngelo et al.(6) and Truong and Heaney (7) stating that the company's growth has a significant negative impact on the DPR.

Free cash flow (FCF) was a significant effect on the dividend payout ratio (DPR) with positive direction, where the coefficient ( $\beta$ ) 132,01 and p-value (Sig) 0,001. The results of this study were in accordance with research conducted by Fenn and Liang (8), and Brown et al. (2003) who found evidence of FCF had a significant positive effect on dividends. Leverage (DER) was no significant effect on the dividend payout ratio (DPR) with positive direction, where coefficient $(\beta)$ 0,155 and p-value (Sig) 0,296. The results of this study confirm that research conducted by Huston (13) and Kouki (14) leverage has a not significant positive effect on the DPR.

Dividend payout ratio (DPR) was a significant effect on the value of the company with a positive direction, where the results of analysis using the PLS obtained an influence of 0.341 with a p-value of 0.031 . the Research shows that dividend has a significant positive effect on company value.

\section{REFERENCES}

8. Husnan, Suad, Dasar-dasar teori Porthopolio dan Analisa sekuritas, Edisi ketiga, AMP,YKIN.(2001)

9. Khoirul Hikmah, Analisis Faktor-faktor yang mempengaruhi Kebijakan DevidenPendekatan Teori Stakeholder Yogyakarta. (2010)

10. Abdelsalam, Omneya, Ahmed El-Masry and Sabri Elsegini. Board composition, 0wnership structure and dividend policies in an emerging market: Futher evidence from CASE 50. Man. Finance, 34 (12), (2008). 953-964.

11. Chen, Donghua, Ming Jian, Ming Xu. Dividend for tunneling in regulated economy:The Case of China. Pasific-Basin FinanceJournal, Vol.17, (2009): pp209-223.

12. Grullon, Gustavo, Roni Michaely, Shlomo Benartzi and Richard H. Thaler. Dividend Changes Do Not Signal Changes in Future Profitability. Journal of Business, 78(5), (2005): pp. 1659-1682.

13. DeAngelo, Harry, Linda DeAngelo and Rene' M. Stulz. Devidend Policy and the Earned/Contributed Capital Mix: A Test of the Life-Cycle Theory. Jounal of Financial Economics, Vol 81, (2006): pp 227-254

14. Truong, Thanh and Richard Heaney. Largest shareholder and dividend policy around the world. The Quarterly Review of Economics and Finance, Vol. 47, pp. 667-687. (2007). 
15. Fenn, George W. And Nellie Liang. 2001. Corporate Payout Policy and Managerial Stock Incentives. Journal of Financial Economics. Vol. 60, pp, 45-72.

16. Manos, Ronny. Capital Structure and Dividend Policy: Evidence From Emerging Markets. Dissertation. Departement of Accounting and Finance, The Business School, University of Birmingham.(2001)

17. Gong, Jaisik. Three Essays in Dividend Policy. Dissertation. Louisiana State University and Agricultural and Mechanical College. (1992).

18. Holmen, Martin, John D. Knopf and Stefan Peterson. Inside Shareholders Effective Tax R Husnan, Suad 2001, Dasar-dasar teori Porthopolio dan Analisa sekuritas, Edisi ketiga, AMP,YKIN.(2008)

19. Renneboog, Luc and Grzegorz Trojanowski. Control Structures and Payout Policy. Managerial Finance, 33(1),(2007): pp. 43-64

20. Huston, Jeffrey L, Determinants of Dividend Policies Among Regulated Utilities. Dissertation Graduate Faculty of the School of Business and Technology Management.(2008)

21. Kouki, Mondher. Stock Options and Firm Dividend Policy: Evidence From Toronto Stock Exchange, International Research Journal of Finance and Economics, Issue 25, (2009): pp. 97-113. 